\title{
THE CHANGES IN BODY BUILD AND STRENGTH IN FEMALE AFTER A 4-MONTH COMBINED JUDO AND STRENGTH TRAINING PROGRAM
}

\author{
ZMIANY BUDOWY CIAŁA I SIŁY U KOBIET PO OKRESIE 4-MIESIĘCZNEGO \\ TRENINGU JUDO I TRENINGU SIŁOWEGO
}

${ }^{1}$ Department of Physical Anthropology, University School of Physical Education in Wrocław, Poland

${ }^{2}$ Department of Individual Sports, University School of Physical Education in Wrocław, Poland

${ }^{3}$ Department of Combat Sports, University School of Physical Education in Wrocław, Poland

S u m m a r y

In judo great significance is attached to the development of strength, which is crucial for performing offensive and defensive actions during fights. Another aspect of strength training is improvement of body build and general physical health of female athletes. The present study aims to estimate the changes of strength and body composition in non-elite female judoists from academic sports clubs after a combined judo and strength training program.

The study examined changes in body build and muscle strength in 20 female judoists participating in judo training and additional adaptive strength training. The anthropometric, physical and motoric measurements were performed twice at four months interval, before and after a combined training program.
After the completion of the training program, significant increases of about $10 \mathrm{~kg}$ in back muscle strength and of about $2 \mathrm{~kg}$ in hand grip strength were noted. No increases in muscle mass and body girths were observed; however, fat mass decreased for about $0.6 \mathrm{~kg}$, which was additionally confirmed by skinfolds thickness measurements. Body mass and BMI remained unchanged. The analysis using Sheldon's somatotypes revealed a tendency towards lower endomorphy among the studied judoists after four months training period. The results of the present study indicate that even experienced but non-elite academic female judoists could improve their back muscle strength, handgrip strength, and body composition by completing the proposed strength training program along with judo training.
Rozwój siły mięśniowej jest ważnym elementem treningu judo, ponieważ duża siła umożliwia zdobycie przewagi nad przeciwnikiem podczas walki. Ważnym aspektem treningu siłowego jest też poprawa budowy ciała i ogólnego zdrowia fizycznego zawodniczek. Prezentowane badania mają na celu ocenę zmian w budowie ciała i sile zawodniczek judo z akademickich klubów sportowych pod wpływem dodatkowego treningu siłowego.

Badano zmiany w masywności ciała i składzie tkankowym ciała u 20 zawodniczek judo średniej klasy przed i po okresie 4-miesięcznego treningu siłowego prowadzonego metodą adaptacyjną według Stefaniaka. Zaobserwowano u kobiet zwiększenie siły mięśni grzbietu o $10 \mathrm{~kg}$ i siły ścisku ręki o $2 \mathrm{~kg}$. Nie odnotowano istotnego zwiększenia masy mięśniowej ani obwodów mięśniowych zawodniczek, natomiast masa tłuszczu zmniejszyła się średnio o $0.6 \mathrm{~kg}$. Po okresie treningu siłowego zaobserwowano u zawodniczek judo także zmniejszenie grubości fałdów skórno-tłuszczowych. Także analiza somatotypów metodą Sheldona 
wykazała nieznaczne zmniejszenie endomorfii. Ogólna masywność ciała (BMI) pozostała na stałym poziomie.

Wyniki badań wskazują, że zastosowanie dodatkowego treningu siłowego u judoczek skutkuje poprawą siły mięśni grzbietu i siły ścisku ręki, a także składu tkankowego ciała. Zmiany takie są pożądane zarówno pod względem efektów sportowych jak też ogólnego zdrowia zawodniczek.

Key words: non-elite female judoists, strength exercises, somatotype, body composition Stowa kluczowe: zawodniczki judo, ćwiczenia siłowe, somatotyp, skład tkankowy

\section{INTRODUCTION}

Strength training is often used by athletes to increase their muscle strength, power and endurance, alter their body composition and, ultimately, attain better sport results $[1,2,3,4]$. Strength training brings about changes in muscle size and structure, muscle cross-sectional area, and also increases muscular strength by improving muscle function $[5,6]$. Some authors indicate that in martial arts such as judo, strength training can potentially improve male competitors' strength and agility [7], what is especially advantageous in experienced athletes adapted to previous judo training. Effects of training on muscle hypertrophy and adipose tissue reduction are the most visible during the initial period of training $[8,9,10]$.

The responses of female judoists to training loads are fairly specific and mostly depend on differences in their body composition and hormonal profile [7, 11, 12]. Therefore, the selection of exercises in strength training programs should be to female competitors' needs. In judo, the great significance is attached to the development of strength and muscular endurance, which is crucial for performing offensive and defensive actions during dynamic judo fight $[13,14]$. Numerous judo throwing or grappling techniques are based on the strength component which can secure an advantage over the opponent. Research comparing elite and nonelite judo competitors proved that elite judokas featured not only a more superior fitness profile than non-elite athletes, but also seemed to have greater arm muscle mass with similar body fat percentage [15].

The control of body mass as well as hydration is very important for the evaluation of strength training effectiveness in female judo competitors. With regard to judo weight categories, the stability of body mass with improvement in muscle mass and strength is of crucial significance. Previous findings indicated that reductions in intracellular water increased the risk of losing grip strength in elite judoists [14].

The present study proposes to introduce an adaptive strength training program in addition to judo training in order to improve the strength and body composition of experienced but non-elite female judoists from academic sports clubs. It was assumed that adaptation to judo training in athletes with long experience in judo does not induce visible effects in body build and strength, but the improvement of athletes' biological condition could be reached by additional strength training program based on adaptive method [16].

The present study was conducted as part of the Academic Sport Development program which is expected to produce practical solutions to improve the performance of academic athletes in Poland. The variables chosen for the analysis were easily accessible and important for judo performance, and are of interest to judo trainers cooperating in the project.

\section{MATERIALS AND METHODS}

\section{Participants}

The study group comprised 23 female judoists training in the academic sports clubs in Wroclaw (Poland) and taking part in regional and national judo competitions (age 20-23 years, $M_{\text {body height }}=165.8 \mathrm{~cm}$ +/- $5.3 \mathrm{~cm}$ ). Their judo training experience ranged from 4 to 10 years (degree above the rank of 3rd kyu and below the rank of 1 st dan). The recruited judoists at the time of the study were not at the competitive stage of their training cycle.

All the judoists were informed of the benefits and risks of the investigation and expressed their voluntary consent to participate in the study. The study was approved by the appropriate Ethics Committee. The participants completed also a medical history and diet questionnaire: they were healthy, did not undergo any treatment for chronic diseases, nor used any special diets or vitamin supplements; their diet was balanced. The participants received an explanation of their data. Three women were excluded from the study because of infections and long absences during judo training and strength training.

\section{Procedure}

Participants' body build and strength were measured before and after a 16-week period of combined training. Female athletes attended judo training sessions three times a week $(4.5+/-0.5$ hours 
per week). They also started a supplementary training program based on Stefaniak's adaptive method (twice a week, 2 hours per week) [16]. Strength training program consisted of strength exercises performed under the trainer's supervision: barbell squats, barbell lunges, stiff-legged barbell deadlifts, bent-over barbell rows, barbell bench press, standing cable crossover, dumbbell overhead shoulder press, dumbbell lateral raises, bent over cable rows, underhand barbell curls, alternate hammer curls, barbell side bends, mountain climber, hanging knee raises, ab crunches [16].

Anthropometric measurements were carried out with use of GPM anthropometry kit (Siber Hegner Machinery Ltd, Switzerland) [17]. Body height (B-v) was measured with an anthropometer (to the nearest $0.1 \mathrm{~cm}$ ), width of elbow and knee (epiphysis: $\mathrm{cl}-\mathrm{cm}$, epl-epm) with a small bone caliper (to the nearest 0.1 $\mathrm{cm}$ ), and circumferences of the upper and lower extremities with an anthropometric tape (to the nearest $0.1 \mathrm{~cm})$. Skinfold thickness was measured with a Tanner/Whitehouse skinfold caliper (Holtain, UK) to the nearest $0.2 \mathrm{~mm}$. Body mass was measured with standard electronic scales to the nearest $0.1 \mathrm{~kg}$. Bioelectrical impedance analysis (BIA-101 Anniversary Sport Edition, Bodygram 1.3.1., Akern, Italy) was used for body composition assessment. Resistance and reactance were measured in the lying position in standard conditions, according to the manufacturer's guidelines. The judoists' left and right hand grip strength was measured with a hand dynamometer, and back muscle strength with a back muscle dynamometer (Takei Scientific Instruments Co. Ltd, Japan).

\section{$\underline{\text { Statistical Analyses }}$}

The reliability of the measurements was ensured by taking a complete set of measurements three times by the same experienced anthropometrists (each measuring the same group of variables before and after the training period). The mean values of the three pretraining and three post-training measures were used for the analysis. The measurement reliability was assessed [18]. The intra-observer technical error of measurement was between $0.2 \mathrm{~mm}$ and $0.6 \mathrm{~mm}$ for skinfold thickness measurements, and between $0.1 \mathrm{~cm}$ and $1.0 \mathrm{~cm}$ for circumference measurements.

On the basis of the anthropometric measurements the participants' Body Mass Index was calculated and Sheldon's somatotypes were determined as modified by Carter and Heath [19]. The levels of ectomorphy, mesomorphy and endomorphy were determined twice for each participant. The percentage increase of dependent variables was calculated based on the difference between the pre- and post-exercise values, which was divided by pre-exercise values and multiplied by 100 .

Paired sample t-test for repeated measures was used in the statistical analysis. All dependent variables were checked for normality using the Shapiro-Wilk test. Levene's test was used to test the homogeneity of variance. All statistical analyses were performed using Statistica 12 by Statsoft $^{\circledR}$. The diagrams were made with Microsoft ${ }^{\circledR}$ Office Excel 2003. The variability of somatotypes were analyzed with SANOVA (Somatotype Analysis of Variance) using the Somatotype Calculation and Analysis software (Sweat Technologies $^{(\mathcal{O}}$ ). The level of statistical significance was set at $\mathrm{p} \leq 0.05$.

\section{RESULTS}

After a 4-month period of the combined judo and strength training program significant increases were noted in the female athletes' back muscle strength (for about $10 \mathrm{~kg}$ ), right hand grip strength (for about $2 \mathrm{~kg}$ ), and left hand grip strength (for $1.5 \mathrm{~kg}$ ). These changes amounted to $12.5 \%, 6.5 \%$ and $5.0 \%$, respectively, compared with pre-training values (Figure 1). Before the strength training the judoists' mean back muscle strength was $78.6+/-18.1 \mathrm{~kg}$, whereas after 16 weeks of training it increased to $88.4+/-19.6 \mathrm{~kg}$ (Student's ttest, $\mathrm{t}=-4.06, \mathrm{p}=0.001)$. The left and right hand grip strength in the pre-training measurement reached the mean values of $31.4+/-4.1 \mathrm{~kg}$ and $30.2+/-4.4 \mathrm{~kg}$, respectively. After the 4-month training period the right hand grip strength increased to $33.6+/-4.3 \mathrm{~kg}$ (Student's t-test, $\mathrm{t}=-3.86, \mathrm{p}=0.002$ ), and the left hand strength to $31.7+/-4.5 \mathrm{~kg}$ (Student's t-test, $\mathrm{t}=-2.67$, $\mathrm{p}$ $=0.019$ ).

The female judoists' fat-free mass and muscle mass did not change significantly; however, their fat mass decreased resulting in a slight reduction of mean body mass - for about $1.2 \%$ compared to pre-training values (Figure 1). Before the strength training program the competitors had a mean body mass of $61.8+/-8.5 \mathrm{~kg}$, fat-free mass of $44.7+/-5.6 \mathrm{~kg}$, and fat mass of 17.2 $+/-3.5 \mathrm{~kg}$. After the training program their mean body mass was $61.1+/-8.1 \mathrm{~kg}$ (Student's t-test, $\mathrm{t}=1.43, \mathrm{p}=$ 0.176 ) and fat-free mass $44.5+/-5.1 \mathrm{~kg}$ (Student's ttest, $\mathrm{t}=-0.19, \mathrm{p}=0.855)$, while their fat mass 
decreased significantly to $16.6+/-3.3 \mathrm{~kg}$ (Student's ttest, $\mathrm{t}=2.85, \mathrm{p}=0.011$ ).

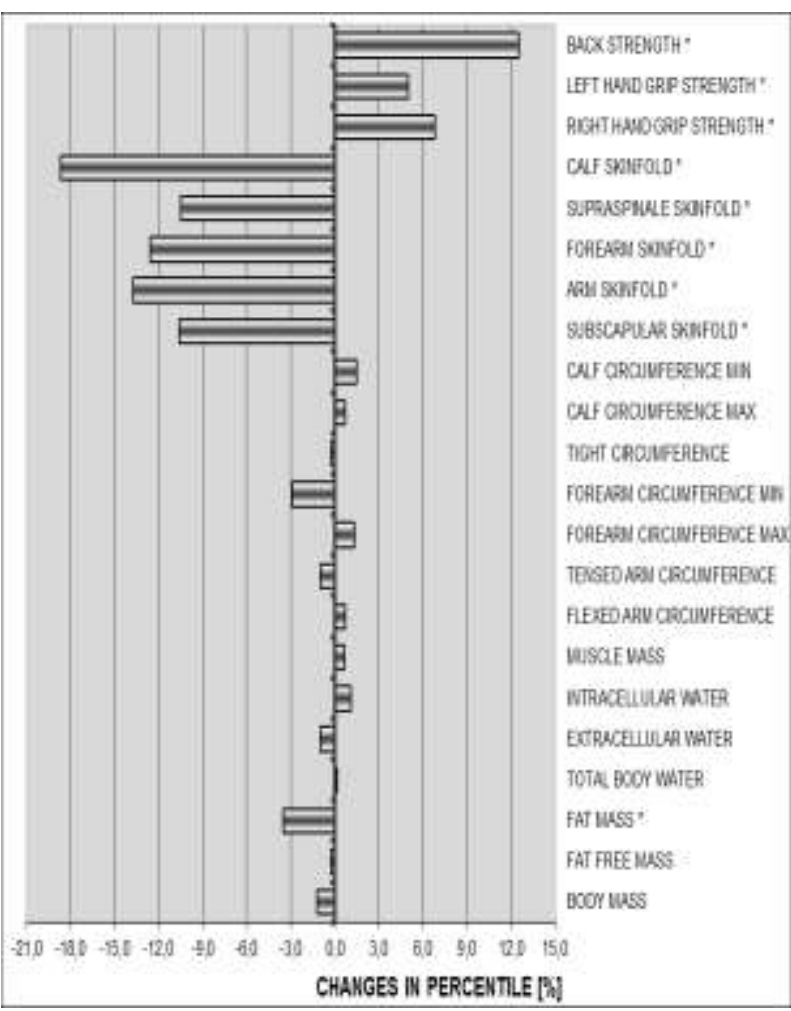

Fig. 1. The changes of measured variables in female judoists compared to pre-training values

Significant changes marked by $*(\mathrm{p}<0.05)$

Ryc. 1. Zmiany cech pomiarowych u zawodniczek judo po 4 miesiącach treningu $w$ stosunku do wartości przed okresem treningu

Zmiany istotne statystycznie $(\mathrm{p}<0.05)$ oznaczono gwiazdką *

The mean muscle mass before the training program was $30.7+/-3.9 \mathrm{~kg}$, and after four months $-30.9+/-3.6$ $\mathrm{kg}$ (Student's t-test, $\mathrm{t}=-0.39, \mathrm{p}=0.706$ ). No significant changes in total body water were observed: $32.7+/-4.1 \mathrm{~kg}$ pre-training and $32.8+/-3.8 \mathrm{~kg}$ posttraining (Student's t-test, $\mathrm{t}=-0.10, \mathrm{p}=0.918$ ). However, a slight increase in intracellular water was noted from $18.6+/-2.4 \mathrm{~kg}$ to $18.8+/-2.2 \mathrm{~kg}$ (Student's $\mathrm{t}$-test, $\mathrm{t}=-0.61, \mathrm{p}=0.552)$. These changes amounted to $1.1 \%$ compared to pre-training values (Figure 1 ). The extracellular water volume amounted to $14.1+/-1.9 \mathrm{~kg}$ and $14.0+/-1.8 \mathrm{~kg}$ in the two consecutive measurements (Student's t-test, $\mathrm{t}=0.57, \mathrm{p}=0.579$ ).

The changes in body composition had not significant effect on the competitors' body slenderness (Body Mass Index). Before the strength training program, their mean BMI amounted to $22.5+/-2.2$ $\mathrm{kg} / \mathrm{m}^{2}$, and after the training period to $22.1+/-2.2$ $\mathrm{kg} / \mathrm{m}^{2}$ (Student's t-test, $\mathrm{t}=1.76, \mathrm{p}=0.102$ ).

Table I. Body girths in female judoists before and after the 4-month training period

Tabela I. Obwody ciała u zawodniczek judo przed $i$ po okresie 4-miesięcznego treningu

\begin{tabular}{|c|c|c|c|c|c|c|}
\hline \multirow{2}{*}{ Girth [cm] } & \multicolumn{2}{|c|}{ Before training } & \multicolumn{2}{|c|}{ After training } & \multicolumn{2}{|c|}{ Student's t-test } \\
\hline & Mean & SD & Mean & SD & $\mathrm{t}$ & $\mathrm{p}$ \\
\hline $\begin{array}{l}\text { Flexed arm girth } \\
\text { Ob. ram. w } \\
\text { spoczyn }\end{array}$ & 28.0 & 1.9 & 28.2 & 2.0 & -0.82 & 0.4279 \\
\hline $\begin{array}{l}\text { Tensed arm girth } \\
\text { Ob. ram. } \\
\text { napiętego } \\
\end{array}$ & 30.0 & 2.1 & 29.8 & 2.2 & 1.07 & 0.3043 \\
\hline $\begin{array}{l}\text { Forearm girth } \\
\text { max } \\
\text { Ob. przedram. } \\
\text { max } \\
\end{array}$ & 23.7 & 1.7 & 24.1 & 1.7 & -1.47 & 0.1658 \\
\hline $\begin{array}{l}\text { Forearm girth min } \\
\text { Ob. przedram. } \\
\text { min }\end{array}$ & 16.0 & 1.1 & 15.5 & 0.9 & 2.16 & 0.0600 \\
\hline \begin{tabular}{|l|} 
Thigh girth \\
Ob. uda \\
\end{tabular} & 56.8 & 4.3 & 56.6 & 4.4 & 0.28 & 0.7861 \\
\hline $\begin{array}{l}\text { Calf girth max } \\
\text { Ob. podudzia max }\end{array}$ & 35.5 & 3.2 & 35.8 & 2.8 & -0.87 & 0.4006 \\
\hline $\begin{array}{l}\text { Calf girth } \min \\
\text { Ob. podudzia min }\end{array}$ & 22.0 & 1.8 & 22.3 & 2.2 & -1.76 & 0.1022 \\
\hline
\end{tabular}

No significant changes in girths of the arm and the leg were noted (Table 1) but a significant decrease in skinfold thickness did occur (Table 2). These reductions of skinfold thickness amounted to 10-20\% compared to pre-training values (Figure 1).

Table 2. Skinfold thickness in female judoists before and after the 4-month training period

Tabela 2. Grubość fatdów skórno-tluszczowych u zawodniczek judo przed $i$ po okresie 4-miesięcznego treningu

\begin{tabular}{|c|c|c|c|c|c|c|}
\hline \multirow{2}{*}{ Skinfolds [mm] } & \multicolumn{2}{|c|}{ Before training } & \multicolumn{2}{|c|}{ After training } & \multicolumn{2}{|c|}{ Student's t-test } \\
\hline & Mean & SD & Mean & SD & $\mathrm{t}$ & $\mathrm{p}$ \\
\hline $\begin{array}{l}\text { Subscapular } \\
\text { Fałd } \\
\text { podłopatkowy }\end{array}$ & 10.4 & 2.0 & 9.3 & 1.9 & 4.42 & 0.0007 \\
\hline $\begin{array}{l}\text { Arm } \\
\text { Fałd na ramieniu }\end{array}$ & 10.5 & 2.8 & 9.1 & 3.0 & 2.82 & 0.0143 \\
\hline $\begin{array}{l}\text { Forearm } \\
\text { Fałd na } \\
\text { przedramieniu }\end{array}$ & 4.0 & 0.6 & 3.5 & 0.8 & 3.25 & 0.0063 \\
\hline $\begin{array}{l}\text { Supraspinale } \\
\text { Fałd nad grzeb. } \\
\text { biodr. }\end{array}$ & 12.0 & 4.3 & 10.7 & 3.5 & 2.07 & 0.0488 \\
\hline $\begin{array}{l}\text { Calf } \\
\text { Fałd na podudziu }\end{array}$ & 8.5 & 2.5 & 6.9 & 2.5 & 3.39 & 0.0048 \\
\hline
\end{tabular}

The analysis of somatotypes showed that the female athletes became less endomorphic after the completion strength training with judo training (Student's t-test, $\mathrm{t}=4.73, \mathrm{p}=0.000$ ). The average 
somatotype of the female judoists during the first measurement was $3.52-4.58-2.22$. After the training period it amounted to $3.02-4.67-2.33$ (Figure 2). A slight increase of mesomorphy and ectomorphy was observed (Student's t-test, $\mathrm{t}=-0.93, \mathrm{p}=0.365$ for mesomorphy, and $\mathrm{t}=-1.36, \mathrm{p}=0.197$ for ectomorphy).

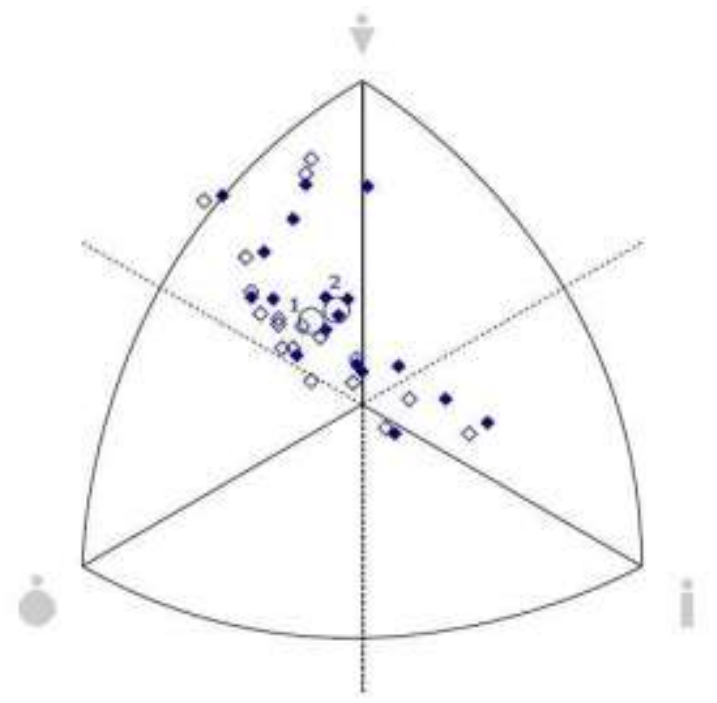

Fig. 2. The distribution of individual somatotypes of female judokas before $(\diamond)$ and after the 4-month training period $(\checkmark)$. The average pre-training somatotype marked as $\left({ }^{1} O\right)$ and post-training somatotype marked as $\left({ }^{2} O\right)$

Ryc. 2. Rozktad somatotypów zawodniczek judo przed ( $\diamond)$ i po 4-miesięcznym okresie treningu ( $\bullet$ ). Uśredniony somatotyp przed rozpoczęciem taczonego treningu oznaczono jako $\left({ }^{1} \mathrm{O}\right)$ a somatotyp po 4-miesiacach jako $\left({ }^{2} \mathrm{O}\right)$

\section{DISCUSSION}

The results of the present study indicate that experienced but non-elite academic female judoists could improve their performance in back muscle strength, handgrip strength and their body composition by completion their judo training with a 16-week strength training program according to adaptive method described by Stefaniak [16]. The examined female judo competitors reached a $10 \mathrm{~kg}$ increase in back muscle strength, and a $2 \mathrm{~kg}$ increase in hand grip strength. After the training program the judoists experienced a decrease in body adiposity, manifested by a reduction of skinfold thickness for $10-20 \%$ and reduction of fat mass for $4 \%$. They also became less endomorphic according to Sheldon's somatotypology. The judoists' fat-free mass and muscle mass remained unchanged. There was also only a slight increase in intracellular water after the training period. The level of hydration, especially proportions between intracellular and extracellular water, was previously shown to be connected with forearm maximal strength, and a greater decrease in strength was observed in the male competitors with reduced intracellular water content [14].

Since the noted changes in fat-free mass and hydration were not significant, it can be concluded that the levels of these body components reached during previous judo training were optimal for their discipline. An increase in muscle mass, if occurred, could have caused an increase in body mass and re-classification into different weight categories, which is not advantageous to female judoists.

The observed changes made the anthropometric profile of non-elite female competitors more similar to the profile of elite judo athletes [20]. These changes are also beneficial for health and can potentially improve the performance during judo competitions [21]. Although it may be difficult to predict competitive success only by body composition and strength, these measures were proven to be important for judoists [14, 20]. This was also confirmed by Gutiérrez-Sánchez et al. in their research on the relationship between judoists' handgrip strength and performance results [22]. They studied male and female competitors who participated in the 2008 Junior Championships of Galicia (Spain). Among the men no differences were found in handgrip strength between the medalists and non-medalists. However, significant correlations were found between handgrip strength and performance results in female judoists [22]. Some earlier studies indicated that thinner and more slender female judoists, who featured lower fat mass and higher muscle mass, attained better results in some physiological tests and International Physical Fitness Tests [23, 24]. Moreover, it was proved that female judoists with lower body fat had a better level of sport preparation in the Special Judo Fitness Test [24]. Abidin and Adam indicated that the percentage of fat mass can be a good predictor of vertical jump height and power of the legs in both male and female martial arts practitioners [25]. However, in male judo competitors the importance of adiposity is not clear, because Drid et al. noted similar body fat percentage in elite and sub-elite judokas [15]. Although it seems that physical variables of elite athletes have little impact on their success in sport [26], in case of non-elite female 
judo practitioners, the presented results may support the direction of judo training.

\section{CONCLUSIONS}

The article proposes to introduce an adaptive strength training to judo training program in order to improve strength and body composition of non-elite female judoists with long experience in their discipline. The analyzed variables are thought to be among numerous determinants of successful judo performance. The motor and somatic effects reached by the female judoists under study were reported within the framework of the mentioned project and were highly appreciated by judo trainers. These changes created better physical conditions for judo practice and better general physical health of female athletes. One of the most advantageous outcomes of this kind of training was that the examined female competitors improved their strength without being reclassified into different weight categories.

The authors declare that there are no Conflicts-ofInterest.

\section{REFERENCES}

1. Faigenbaum AD, Myer GD: Resistance training among young athletes: Safety, efficacy and injury prevention effects. Br J Sports Med, 2010; 44(1): 56-63.

2. Jung AP: The impact of resistance training on distance running performance. Sports Med, 2003; 33(7): 539-552.

3. Otto WH, Coburn JW, Brown LE et al.: Effects of weightlifting vs kettlebell training on vertical jump, strength, and body composition. J Strength Cond Res, 2012; 26(5): 1199-1202.

4. Tanaka H, Swensen $\mathrm{T}$ : Impact of resistance training on endurance performance. Sports Med, 1998; 25(3): 191200.

5. Moore DR, Burqomaster KA, Schofield LM et al.: Neuromuscular adaptations in human muscle following low intensity resistance training with vascular occlusion. Eur J Appl Physiol, 2004; 92: 399-406.

6. Schoenfeld BJ: The mechanisms of muscle hypertrophy and their application to resistance training. J Strength Cond Res, 2010; 24(10): 2857-2872.

7. Saraiva AR, Reis VM, Costa PB et al.: Chronic effects of different resistance training exercise orders on flexibility in elite judo athletes. J Hum Kinet, 2014; 40: 129-137.

8. Newham DJ: Strength, power and endurance. In: Trew M, Everett T, editors. Human Movement. London UK: Churchill Livingstone; 2001.

9. Häkkinen K, Alén M, Komi PV: Changes in isometric force- and relaxation-time, electromyographic and muscle fibre characteristics of human skeletal muscle during strength training and detraining. Acta Physiol Scand, 1985; 125(4):573-585.

10. Ballor DL: Exercises training and body composition changes. In: Roche AF, Heymsfield SB, Lohman TG., editors. Human Body Composition. Leeds UK: Human Kinetics; 1996.

11. Kim E, Dear A, Ferguson SL et al.: Effects of 4 weeks of traditional resistance training vs superslow strength training on early phase adaptations in strength, flexibility, and aerobic capacity in college-aged women. J Strength Cond Res, 2011; 25(11): 3006-3013.

12. Santos E, Rhea MR., Simão $R$ et al.: Influence of moderately intense strength training on flexibility in sedentary young women. J Strength Cond Res, 2010; 24(11): 3144-3149.

13. Bratic M, Radovanovic D, Nurkic M: The effects of preparation period training program on muscular strength of first-class judo athletes. Acta Medica Medianae, 2008; 47(1): 22-25.

14. Silva AM, Fields DA, Heymsfield SB et al.: Relationship between changes in total-body water and fluid distribution with maximal forearm strength in elite judo athletes. J Strength Cond Res, 2011; 25(9): 2488-2495.

15. Drid P, Casals C, Mekic A et al.: Fitness and anthropometric profiles of international vs national judo medalists in half heavyweight category. J Strength Cond Res, 2015; 29(8): 2115-2121.

16. Stefaniak T. Atlas of strength exercises. Part 1 [in Polish]. Wroclaw, Poland: BK Publishing Company; 2006.

17. Martin R, Saller K. Handbook of Anthropology. Part 1 [in Deutsch]. 3rd ed. Stuttgart, Germany: Gustav Fischer; 1957.

18. Ulijaszek SJ, Kerr DA. Anthropometric measurement error and the assessment of nutritional status. Br J Nutr, 1999; 82(3): 165-177.

19. Carter JEL, Heath BH. Somatotyping - development and applications. Cambridge, United Kingdom: Cambridge University Press; 1990.

20. Franchini E, Del Vecchio FB, Matsushigue KA et al.: Physiological profiles of elite judo athletes. Sports Med. 2011; 41(2): 147-166.

21. Amtmann J, Cotton A: Strength and conditioning for judo. Strength Cond J, 2005; 27(2): 26-31.

22. Gutiérrez-Sánchez Á, Soria-Dominguez A, Pérez-Turpin JA et al:: Importance of hand-grip strength as an indicator for predicting the results of competitions of young judokas. Arch Budo, 2011; 7(3): 167-172.

23. Ali PN, Hanachi P, Nejad NR: The relation of body fats, anthropometric factors and physiological functions of Iranian female national judo team. Modern Appl Sci, 2010; 4: 25-29.

24. Smulski W, Wolska B, Jagiełło W et al.: The correlation of general and sport-specific preparation indices of elite female judo competitors with their age-somatic characteristics. Arch Budo, 2011; 7(4): 233-238. 
25. Abidin NZ, Adam MB: Prediction of vertical jump height from anthropometric factors in male and female martial arts athletes. Malays J Med Sci, 2013; 20(1): 39-45.

26. Franchini E, Nunes AV, MoraesJM et al.: Physical Fitness and Anthropometrical Profile of the Brazilian Male Judo Team. J Physiol Anthropol, 2007; 26(2): 5967.
Address for correspondence:

Aleksandra Stachoń

Zakład Antropologii Fizycznej

Akademia Wychowania Fizycznego we Wrocławiu

ul. I.J. Paderewskiego 35 bud. P2

51-612 Wrocław, Polska

tel.: +48713473344

e-mail: aleksandra.stachon@awf.wroc.pl

Received: 6.06.2016

Accepted for publication: 30.06.2016 